\title{
Het grote accountantskantoor, naar een bureaucratie?
}

In het onderhavige proefschrift, op 10 december 1982 verdedigd, wordt de aandacht gevestigd op signalen die op een toenemende tendens tot bureaucratisering ${ }^{1}$ bij grote accountantskantoren duiden. Door middel van analyse (van deductieve aard) wordt de aannemelijkheid van de gesignaleerde trend bevestigd. Er van uitgaande dat het gestelde in overeenstemming is met de realiteit zou de invloed hiervan op de beroepsuitoefening kunnen worden nagegaan. Het is ook mogelijk om onafhankelijk van gesignaleerde ontwikkelingen te onderzoeken hoe de organisatie van een groot accountantskantoor gestructureerd zou moeten zijn en welk regiem nodig is om optimaal bij te kunnen dragen aan de beroepsuitoefening. In ons geval zijn beide wegen bewandeld, zij het dat aan laatstgenoemde weg het meeste aandacht wordt besteed. Dit blijkt reeds uit de doelstelling van de studie die gericht is op: 'factoren die bepalend zijn voor het welslagen van accountantscontrole, voor zover bedoelde factoren in verband staan met het organisatiegebeuren op een groot Nederlands accountantskantoor'.

Deze benadering noopt tot behandeling van twee deelproblematieken. Enerzijds dient te worden vastgesteld hetgeen onder een 'geslaagde accountantscontrole' moet worden verstaan, terwijl anderzijds het organisatiegebeuren op een groot accountantskantoor aan de orde moet komen.

Genoemde thema's zijn uitgewerkt in drie delen, te weten: deel I Samenvatting bevindingen, deel II Identiteit en deel III Affiniteit. Wat is hierbij nieuw dan wel specifiek voor het proefschrift?

Om te beginnen wordt het object van studie benaderd vanuit de invalshoeken- het kenobject - beheersing en zingeving (a). Bij het beschouwen van de identiteit van de accountant wordt een verband gelegd tussen functie, deskundigheid en werkmilieu (b). Het begrip affiniteit (c) ten slotte wordt in twee richtingen benut en wel als bindend element dat mensen er toe brengt om met elkaar een (grote) maatschap te vormen en voorts als uitdrukking van het hebben van belangstelling tot iets in ons geval uitmondend in een bepaalde rol of rollen in de beroepsuitoefening.

Onderstaand volgen enkele kanttekeningen bij de uitwerkingen.

\section{a. De invalshoeken 'beheersing' en 'zingeving'}

Tijdens de promotie werd door één van de opponenten de vraag gesteld of 
het onderscheid tussen beheersing en zingeving wel een wezenlijke bijdrage vormt aan de analyse. Activiteiten krijgen immers vooral zin als ze effectief worden verricht. Effectiviteit en zingeving zouden in elkaar opgaan.

In de beantwoording werd gesteld dat de betekenis van effectiviteit van een andere orde is dan die van zingeving. Bij effectiviteit staat doelrealisering voorop. Effectiviteit geeft evenwel geen uitsluitsel omtrent de kwaliteit van het doel. Een volstrekt verderfelijk en a-sociaal doel kan effectief worden gerealiseerd. Vooral in onze tijdgeest van functioneel denken ${ }^{2}$ doet de behoefte aan een aanvullend criterium zich gevoelen. Het gaat er niet alleen om of we het doel kunnen realiseren, maar of we het ook mogen realiseren en hoe we het realiseren. Zowel na te streven doelen als doelrealisering dienen zinvol te zijn. Beheersing en zingeving vormen beide wezenlijke bakens die gelijktijdig in aanmerking moeten worden genomen. Beheersing zonder acht te slaan op zingeving zal evenals het omgekeerde waarbij een nadrukkelijke, eenzijdige belangstelling voor de zin van dingen bestaat, doodlopen.

Die hier vermelde opvatting geldt evenzo bij het realiseren van controledoelen. Het uitvoeren van een controle-opdracht kan eerst als geslaagd worden aangemerkt indien de controle effectief en efficiënt werd verricht, terwijl tegelijkertijd recht werd gedaan aan allen die bij de controle zijn betrokken.

\section{b. Identiteit}

In eerste instantie wordt de identiteit van de accountant bepaald door zijn functie. Op dit punt heeft Limperg meer dan vijftig jaar geleden zijn 'vertrouwenstheorie' ontworpen. De functie van de accountant wordt hierbij gerechtvaardigd op grond van behoeften van derden, gebruikers van accountantsverklaringen. Op zich is er geen aanleiding deze analyse terzijde te schuiven; er is wel reden tot aanvulling en uitbreiding. We denken hierbij o.a. aan de betekenis van de openbaar accountant ten behoeve van de cliënt en ten behoeve van de gecontroleerde.

Alvorens de in het proefschrift ondernomen aanzet hiertoe kort toe te lichten, staan wij stil bij de aanduiding 'cliënt'. Dit begrip werd nodig geacht daar de belangrijkste communicatiepartner van de accountant per opdracht verschilt. Dat kunnen zijn: aandeelhouders, commissarissen, directie, een commissie verantwoordelijk voor de benoeming van de accountant, een combinatie van personen, enz. 'Cliënt' verwijst in onze studie naar 'de' communicatiepartner(s) ongeacht juridische positie.

$\mathrm{Nu}$ een korte toelichting op de poging een bovenbouw aan te brengen op een Limpergiaanse fundering. In de Limpergiaanse benadering staat het maatschappelijk verkeer centraal. Maatschappelijk verkeer staat hierbij voor derden, gebruikers van accountantsverklaringen. Weliswaar spreekt Limperg mede over de functie van de accountant als 'orgaan van de bedrijfsleiding', terwijl voorts de term 'algemene controle' meer inhoudt dan controle van de jaarrekening-sec. Maar de gedachten hieromtrent zijn nog te weinig uitgewerkt en de hierover gevoerde polemieken zijn inmiddels achterhaald. Vernieuwing in denken is dringend noodzakelijk. Op grond 
van de functie van de accountant ten behoeve van derden moet de accountant tegenover zijn opdrachtgever autonomie claimen. De autonomie van de accountant is functioneel. Deze op zich legitieme opstelling leidt evenwel tot vertekening indien niet tegelijkertijd de rol van de accountant ten behoeve van de cliënt in aanmerking wordt genomen. De werkelijke betekenis van het beroep blijft volstrekt niet beperkt tot de rol van de accountant ten behoeve van derden, gebruikers van accountantsverklaringen. De openbaar accountant zal zich waar moeten maken voor het maatschappelijk verkeer, als geheel. ${ }^{3}$ De cliënt is een belangrijke schakel in dit verkeer. Onlangs schreef Rijnvis een inleiding over dit thema: Wat verwacht het ondernemingsbestuur van de accountant? ${ }^{4}$ Het antwoord is niet mis te verstaan. Indien de accountant zijn rol ten behoeve van de cliënt - in controlerende en adviserende zin - niet effectief vervult, zal hij de toekomst niet overleven. Het is noodzakelijk de theorie van Limperg gebaseerd op de functie van de accountant ten behoeve van derden, gebruikers van accountantsverklaringen (onderbouw) aan te vullen met een analyse van de functie van de accountant ten behoeve van de cliënt (bovenbouw). Een aanzet daartoe werd zowel in deel II als in deel III opgenomen.

Voor een andere factor die van invloed is op de identiteit van de accountant wordt gewezen op zijn deskundigheid. Het ligt in dit verband voor de hand te denken aan accountantscontrole, maar ook aan interne controle als voor de beroepsuitoefening exclusieve terreinen. Een lans wordt dan ook gebroken voor meer fundamenteel onderzoek op het terrein van controle zowel in theoretische als in praktische zin. Interne controle bijvoorbeeld wordt normaliter beschouwd als dimensie van de administratieve organisatie. In werkelijkheid vormt interne controle een eigenschap van het bestuurlijk regiem en van de interne organisatie als geheel. Het wordt hoog tijd kunstmatig aangelegde afscheidingen te slopen en de theorie van interne controle uit een ongewenst isolement te bevrijden. Een accountant die pretendeert deskundig te zijn op het gebied van interne controle zal verder moeten kijken dan zijn 'administratieve neus' lang is. Onderzoek naar opzet en werking van interne controle biedt tevens een gunstige uitgangssituatie om samenhangen tussen disciplines bloot te leggen. Op dit punt kan worden gedacht aan raakvlakken tussen de terreinen van leiding en organisatie, administratieve organisatie, informatica en bedrijfseconomie. Terreinen derhalve die voor accountantscontrole bepalend zijn. Het gevaar is aanwezig dat de benodigde aandacht hiervoor wat wordt verdrongen door nationale en ook internationale ontwikkelingen op juridisch terrein.

\section{c. Affiniteit}

Onderzoek naar het gewenste regiem en structuur van het accountantskantoor vond plaats aan de hand van zogenoemde 'contingency factors' naar de theorie van Mintzberg. Hierbij is gebleken dat vooral machtsverhoudingen alsmede omgevingsinvloeden het krachtigst inwerken op de organisatie van het accountantskantoor. Buiten het 'protocol' van bovengenoemde 'contingency' benadering werd aandacht besteed aan eisen en wensen van organisatieleden en aan eisen voortvloeiend uit het zijn van 'professional'. 
Het is niet goed mogelijk om in enkele pennestreken de overwegingen samen te vatten. Wij volstaan met het noemen van een enkele bevinding. De omgeving van het accountantskantoor is complex en heterogeen; het eerstgenoemde kenmerk noopt tot decentralisatie, terwijl heterogeniteit aanleiding geeft tot differentiatie. Structurering van het accountantskantoor zou afgestemd moeten worden op voor accountants relevante marktsegmenten. Een marktsegment kan worden ingedeeld naar de rol van de accountant, toe te passen technieken alsmede naar kenmerken van de desbetreffende huishoudingen. Dienovereenkomstig kunnen specialisaties worden ontwikkeld. Specialisaties zijn enerzijds cliëntgericht en anderzijds probleemgericht. Aldus vindt rechtvaardiging plaats van grootschaligheid. Hoe kan de bestuurbaarheid en de samenhang tussen de delen van het grote kantoor worden opgeroepen?

Tijdens de promotie vroeg Lievegoed zich op dit punt af: Wie zorgt er voor dat er geen discrepantie ontstaat tussen verbaal beleid en werkelijke vertrouwensverhoudingen?

In de beantwoording werd gewezen op de noodzaak van een samenstel, een mix van voorzieningen. In dit kader vormen twee parameters coördinatiemiddelen bij uitstek, te weten standaardizering van kennis en kunde enerzijds en 'socialization' anderzijds. Door het aanbrengen van vaktechnische normen en vaktechnische herkenningspunten weet men waarop men mag rekenen, weet men wat men van elkaar mag verwachten. Een hechte samenhang heeft evenwel eerst dan kans van slagen indien een geëigende voedingsbodem (socialization) aanwezig is, waardoor mensen bereid zijn voor elkaar op te komen en bereid zijn elkaar in constructieve zin te corrigeren. Bestuurlijke maatregelen dienen primair te worden gericht op de versterking van een dergelijk klimaat. In het verlengde hiervan past het dat ervaren en creatieve partners bij de opdrachtbehandeling (jonge) collegae inschakelen om meer tijd vrij te krijgen voor coaching en begeleiding.

\section{Tot besluit}

Naar de mening van Mintzberg ${ }^{5}$ heeft een 'professional' twee basistaken: '(1) to categorize the client's need in terms of a contingency, which indicates which standard program to use, a task known as diagnosis, and (2) to apply, or execute, that program'. Het 'professionele' is dan ook om te beginnen extern gericht; 'op de voorgrond staat het contact met de cliënt, het zich inleven in de problemen die daar aan de orde zijn' (proefschrift pag. 96). Uit hoofde van zijn beroep gaat de accountant voorts een zelfstandig economische naast een vertrouwensrelatie aan met cliënten. Deze verhoudingen leiden tot een spanningsveld indien de accountant zijn beroep uitoefent vanuit een grootschalige organisatie op grond waarvan hij mede onderworpen is aan een centraal bestuur, organisatiereglementering en centrale toetsing. Naarmate de omvang van het accountantskantoor toeneemt, zal ook het gebruik van bureaucratische organisatiemiddelen door het centrale bestuur worden geïntensiveerd. Hierdoor zullen spanningen dysfunctioneel kunnen uitwerken. De druk van het regiem kan uiteindelijk zo groot worden dat reglementering en hiërarchie het winnen van inspiratie 
en creativiteit. In dat geval wordt de essentie van het professionele aangetast. Anderzijds moet worden gewezen op de plichten van bestuurders van het accountantskantoor om het goed functioneren van alle delen van het kantoor te bevorderen en de kwaliteit van de werkzaamheden te handhaven. Hoe hierbij beheersing en zingeving te verkrijgen?

In dit kader worden een aantal aanbevelingen uitgewerkt o.a.:

a. De omvang van het kantoor blijve begrensd. Het kantoor moet juist groot genoeg zijn om in beginsel ieder type controle-opdracht te kunnen aanvaarden; anderzijds moet het kantoor klein genoeg zijn om de (machine) bureaucratie buiten de deur te kunnen houden.

$b$. Een strenge selectie van organisatieleden en een evenwichtige carrièrebegeleiding kan niet worden gemist.

c. Training en vorming dienen doorlopend op alle niveaus plaats te vinden.

d. De kwaliteit van de werkzaamheden wordt primair decentraal bewaakt binnen operationele eenheden; deze eenheden brengen periodiek en stelselmatig verslag uit omtrent evaluatiebevindingen aan het centrale bestuur. Aldus wordt grootschaligheid gecombineerd met kleinschalige bedrijfsvoering.

e. Het centrale bestuur is gemachtigd zo nodig binnen operationele eenheden in te grijpen. De rechtszekerheid van professionals wordt hierbij gehandhaafd door het functioneren van een Raad van Beroep en de verantwoordingsplicht van bestuurders aan andere daartoe bevoegde organen.

f. Bovengenoemde maatregelen zullen falen bij het ontbreken van een geëigende voedingsbodem zoals eerdergenoemd.

Tot zover enkele kanttekeningen omtrent een problematiek gevormd door de botsing van twee werelden en wel die van de accountant als individuele vrije beroepsuitoefenaar en die waarbij de accountant deel uitmaakt van het accountantskantoor als instituut. De individuele accountant praktizeerde aanvankelijk op een wijze die wel het 'traditionele professiemodel' wordt genoemd; de accountant werkzaam vanuit het grote accountantskantoor zou zich daarentegen dienen te gedragen volgens de spelregels van het zogenoemde 'moderne professiemodel'. Het maken van een keuze tussen de twee modellen wordt door ons evenwel ontraden: beide modellen kunnen niet worden gemist. De cliënt is geinteresseerd in de accountant als persoonlijk vertrouwensman en in het accountantskantoor als verzamelplaats van 'know-how'.

'De rollen corresponderende met zowel het klassieke als met het moderne professiemodel zijn nodig, beide rollen dienen met elkaar te worden verzoend. Het is de kracht van grootschaligheid om een dergelijke samenbundeling mogelijk te maken.' (Proefschrift, pag. 153)

De handelseditie is verkrijgbaar bij Kluwer, Deventer. 
Noten

1 Voor de goede orde wordt opgemerkt dat het woord 'bureaucratie' (althans in deze studie) staat voor een beheersingssysteem dat aan bepaalde kenmerken voldoet.

2 Dingen, organisaties enz. hebben geen geisoleerd doel in zichzelf; legitimering vindt plaats aan de hand van de maatschappelijke betekenis en/of wijze van functioneren.

3 Dit verkeer wordt a.a. gevormd door opdrachtgevers, gecontroleerden, controleurs, overheid en gebruikers. In het proefschrift wordt op de belangen per categorie ingegaan.

4 Ekonomies Bulletin, Vrije Universiteit, Amsterdam, nummer 2, oktober 1982, pag. 9 e.u

5 Mintzberg (1979), The structuring of organizations, pag. 352. 